\title{
The Role of Third States in the EU Maritime Security Strategy: A Case Study of the South Atlantic States
}

\author{
André Panno Beirão \\ Brazilian Naval War College, Rio de Janeiro, Brazil
}

\begin{abstract}
The global challenges to maritime security have long outnumbered the classic interstate war. Increasingly, the new threats have assumed the most real risks, whether human, weapons or drugs traffic, piracy, illegal fishing among others. Some of these challenges, even if they are not in the European Union's primary strategic maritime area, they have relevant impacts on this. The unstable region of the Gulf of Guinea, for example, with its cases of armed robbery, piracy, or even trafficking (mainly human and drug trafficking) has attracted attention to the several EU Member States, with individual policies that are often poorly articulated. This paper is the result of field research with stakeholders from 17 South Atlantic countries (the research delimitation occurred in South Atlantic Peace and Cooperation Zone [ZOPACAS] members) and concludes that the exogenous (European) point of view of the major challenges that encourage the collaborative participation of the South Atlantic are, necessarily, the ones that have most demanded attention and engagement from the EU Members States. For example, the highest local priority in allocating resources available in the African coast Navies has been to face and control smuggling acts. The African States are seeing it as the biggest threat to its maritime security. The widespread problem of piracy appears only as of the third priority of the regional countries. Besides, the perception of the reputation of control centers coordinated by exogenous members (States and individuals) to the region does not result in joint information sharing engagement or even in maritime domain awareness. Thus, this paper that starts from the maritime security's typological conceptual presentation-as a complex, divergent, and convergent concept-presents empirical research and identified actions with potential for greater engagement in the South Atlantic region. It seeks to demonstrate the need for EU analysis of exogenous problems should increase the local point of view problem. It therefore serves both the reflection on many of the action points of the Action Plan of European Union Maritime Security Strategy (EUMSS) and on the competences involved by the EU, in particular, as regards the actual role of the EU and its Member States in relation to the maritime security aspects of EU internal policies and EU external relations, EU in negotiating, concluding and implementing international agreements in this area. On the other hand, it also relates to the accountability of EU Member States with other involved actors (the South Atlantic States, regional organizations, and/or local/multinational private actors).
\end{abstract}

Keywords: maritime security, South Atlantic, security threats

André Panno Beirão, PHG on International Law at UERJ; MSc on Political Sciences at UFRJ; MSc on Naval Sciences at Brazilian Naval War College; Law Bachelor at UNIRIO, senior researcher, Brazilian Navy Political and Strategic Studies Centre, Pro-Defesa IV CAPES-MD (Maritime Policies Observatory), Rio de Janeiro, Brazil 


\section{The Delimitation of the Security Concept}

Security can be considered a macro concept that has given the scope of endo-concepts that inserts it. Many definitions are discussed. However, they all seem directed to the inclusion of two aspects: a subjective-the sensation or perception of those who are influenced by that region, and the other objective-by the set of actions put in practice that mitigate the identified threats.

Nevertheless, both aspects, the subjective and the objective, start from the premise of being approached in their insert's context, whether temporal or geographic. That is, it has to be approached under a particular region and regime. Therefore, they presuppose a certain jurisdiction and territoriality where they inhabit those who are affected and responsive to the intended security. In this given region, there is a presumed norm of social interaction of all those involved and the authority of someone to act in favor of the social good. This is not the case in the maritime scenario where humanity, the main variable of the subjective concept of security, inhabits.

Grotius (1609) said: The sea has no borders! This indivisible liquid mass passed through innumerable theories and reflections: res communis, res nullius, mare clausum, and mare nostrum among others more contemporary. Thus, when one intends to analyze the concept of security in this no-land area, one must try to make associations and lessons that are typical of the terrestrial state territorial sphere for a completely different environment. That is the challenge! That is why maritime security has been an exciting topic for research and debate.

\section{Delimiting Maritime Security}

The first point to emphasize is the delineating difficulty of the object-maritime security. In the face of linguistic and therefore conceptual differences in what we mean by maritime security, these distinctions must be delimited. This may sound trivial, but it is not! In the English and French languages, there is a distinct ethos that carries different concepts: security and safety, in English and, securité and surreté, in French. In the Spanish and Portuguese languages, there is only one word that brings together both concepts: segurança, in Portuguese and Seguridad, in Spanish. It is certain that segurança-safety is distinct from security-safety, especially in the maritime context. While the former has a strong shipping bias without risk to the physical integrity of the seamen, the latter has a strong link with the possibility of threats and violent actions that may occur at sea (Beirão \& Pereira, 2014). Therefore, the object of this work is related to the second bias-segurança-security, although this is not completely exclusive of the first.

Once this delimitation has been made, what maritime security means, and which are the causes of insecurity, an intriguing topic of the current debate, some contemporary maritimists and internationalists have focused on their deepening, such as Christian Buerger (2014) from Cardiff University, Geofrey Till (2012), King's College London, and James Kraska and Raul Pedrozo (2013), US Naval War College, among others. However, all of them converge their debate on the difficulty of conceptual delimitation of maritime security.

Faced with this difficulty, this work intends to delimit their understanding with a proposed typology. The typology is a very useful tool in social sciences when the object of study is influenced by characteristics of distinction and, therefore, needs delimitation. That is why we have done the choice of the typological methodology for the concept of maritime security. Maritime security is considered to be a complex, convergent, and divergent concept. 
In the second part of the paper, these three typologies will serve to particularize the concept approach to the desired region: The South Atlantic.

Complex - because it is approached by several levels, quite different from each other. For example, there are approaches with universalizing tendencies, when the $\mathrm{UN}$, itself, issues resolutions for broad purposes. Other initiatives of universal aspiration have also been adopted when the IMO put on the action a lot of resolutions, such as the Suppression of Unlawful Acts at Sea (SUA-1988) and when its Maritime Safety Committee (MSC) includes, among its tasks, attention to maritime security.

The regional level or multilateral international organizations of more restricted arrangements also have strong initiatives. For example, in 2011, NATO included the theme among its main objectives, through the Alliance Maritime Strategy (2011), as well as the African Union and the European Union, in 2014.

From the state initiatives point of view, examples can also be cited. The United States of America, in 2004, among the pioneers, proposed their "National Maritime Security Policy" as well as the United Kingdom, in 2014, in its Maritime Security Strategy.

However, the approach sometimes deserves even greater specificity. Beyond the universal, multilateral, and state-level ones, it should be emphasized that, in many cases, there is still an intra-state institutional level, since it is not uncommon for the theme to be a concurrent, complementary, or shared attribution of Navies, Coast Guards, or even other national institutions. Therefore, given the diversity of levels, the complex approach can be considered, because it is not possible to gather expectations at all levels, except in ethereal and consensual terms.

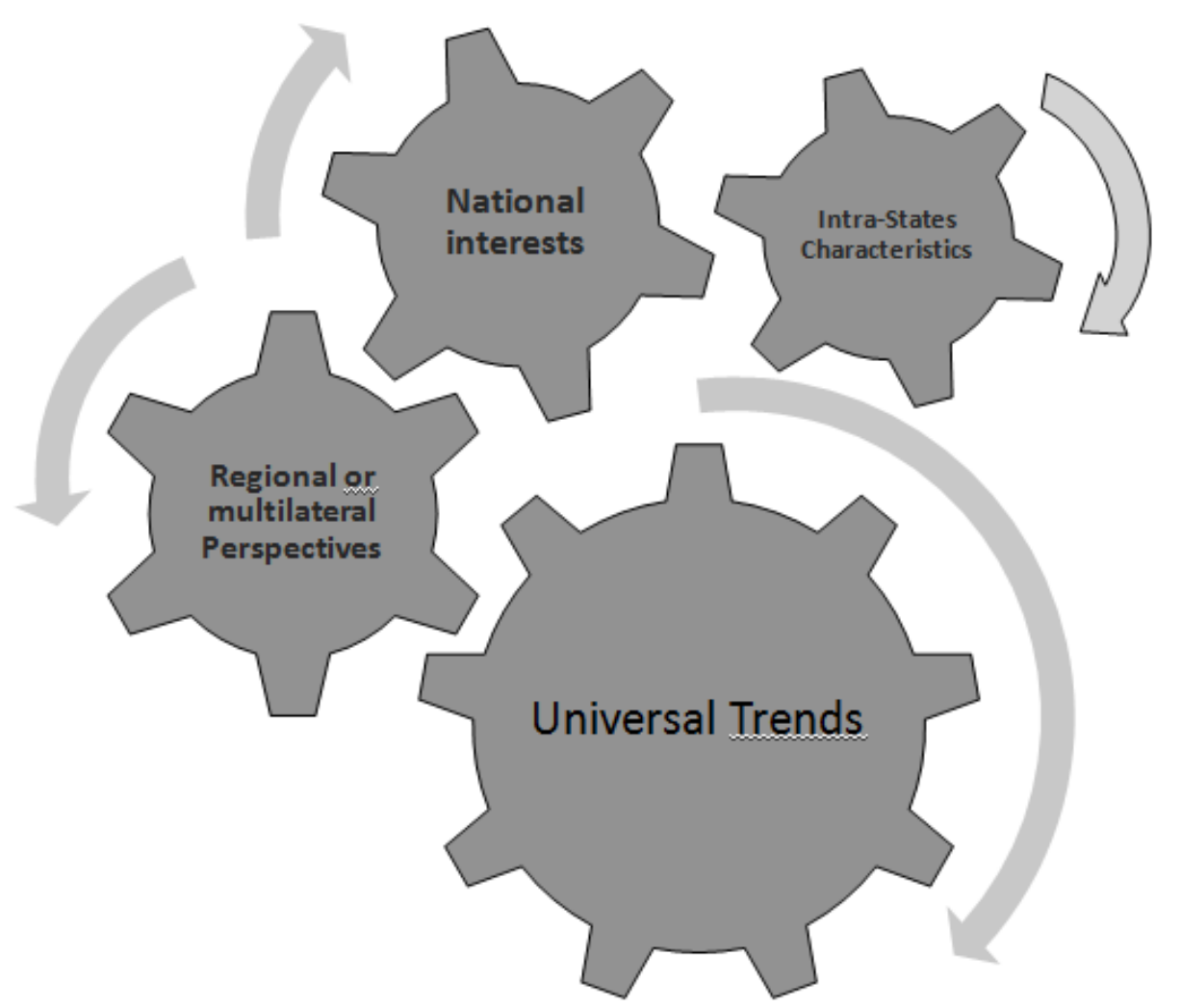

Figure 1. Complex approach of maritime security. 
The proposed typology states that in addition to being "complex", it is considered that the concept of maritime security would be convergent and divergent.

Convergent-because subjective and difficult concepts are often also inserted, such as "universal peace", or more specifically, "good order at sea" or "freedom of navigation". Which "good order" are we talking about? This concept is much relativized according to other interests (state, regional, etc.). Convergent, still, because even thematically thought in the context of safety can also affect the aspect of security, as signaled at this work beginning. The intersection areas between those issues that allow complementary approaches to safety and security have been increasingly strengthened. Perhaps, this conceptual enlargement allowing the convergence of several themes to the concept of maritime security is a trend that aims at filling gaps in international regulation. Convergence on something of general interest can facilitate agreements based on similar interests among stakeholders.

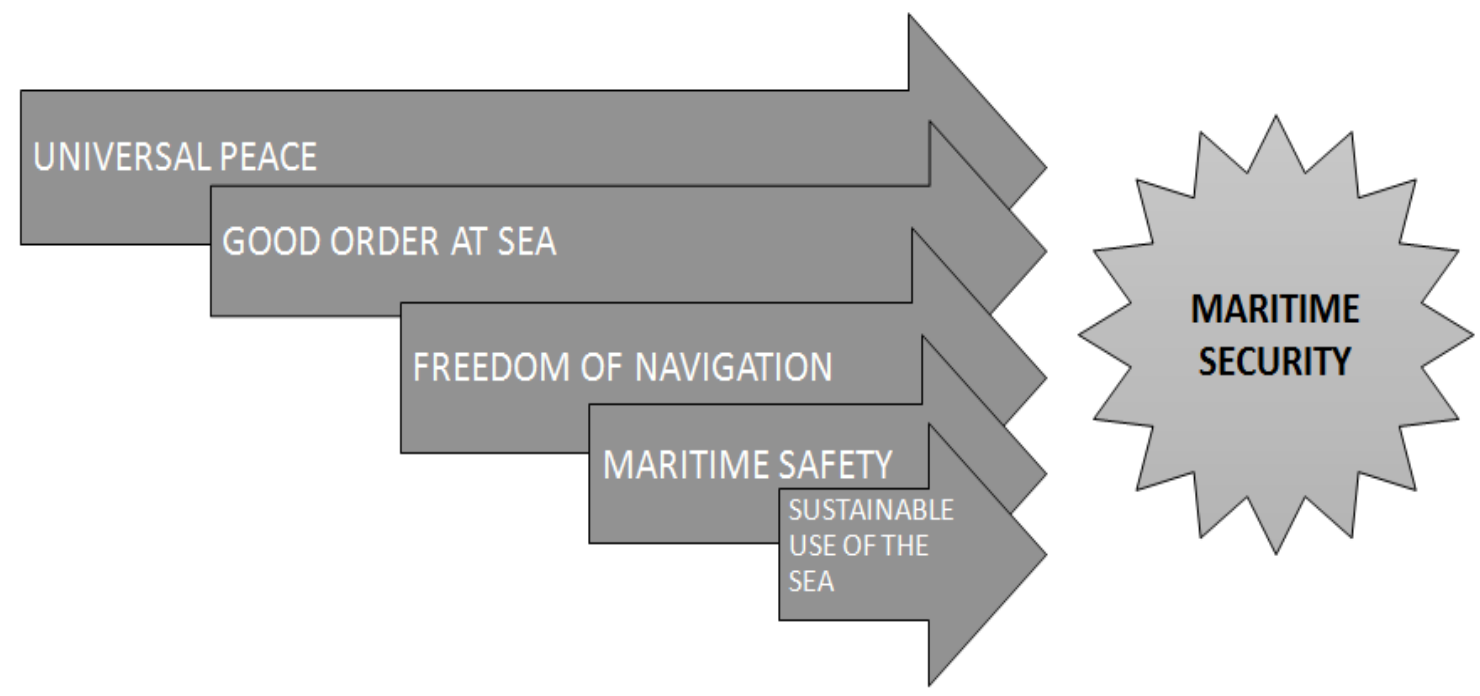

Figure 2. Convergent approach to maritime security.

Concluding the typological delimitation proposed for maritime security, it was considered to be divergent. The term is purposely used here to show that if the center of the theme is, effectively, derived from actions at sea that affect all regular navigation, there are themes that are distant from this center, but which certainly also belong to the broad concept of maritime security. Christian Buerger (2014) proposed four quadrants that influence the theme: national security; human security, the marine environment, and the economic use of the sea. This mapping in four dimensions is complementary to the proposed typology of maritime security because it identifies the three major dimensions of sovereignty proposed by Luigi Ferrajoli (2009): the imperative of internationalization (economic use of the seas), the imperative of human security, and the national dimension. To these imperatives proposed by Ferrajoli, we could add the imperative of the environmental dimension that, from the turn of the 20th century to the 21 st century, it has become a singular point of interests limiting of the aspirations and use of the sea-the environmental imperative (environmental security). 


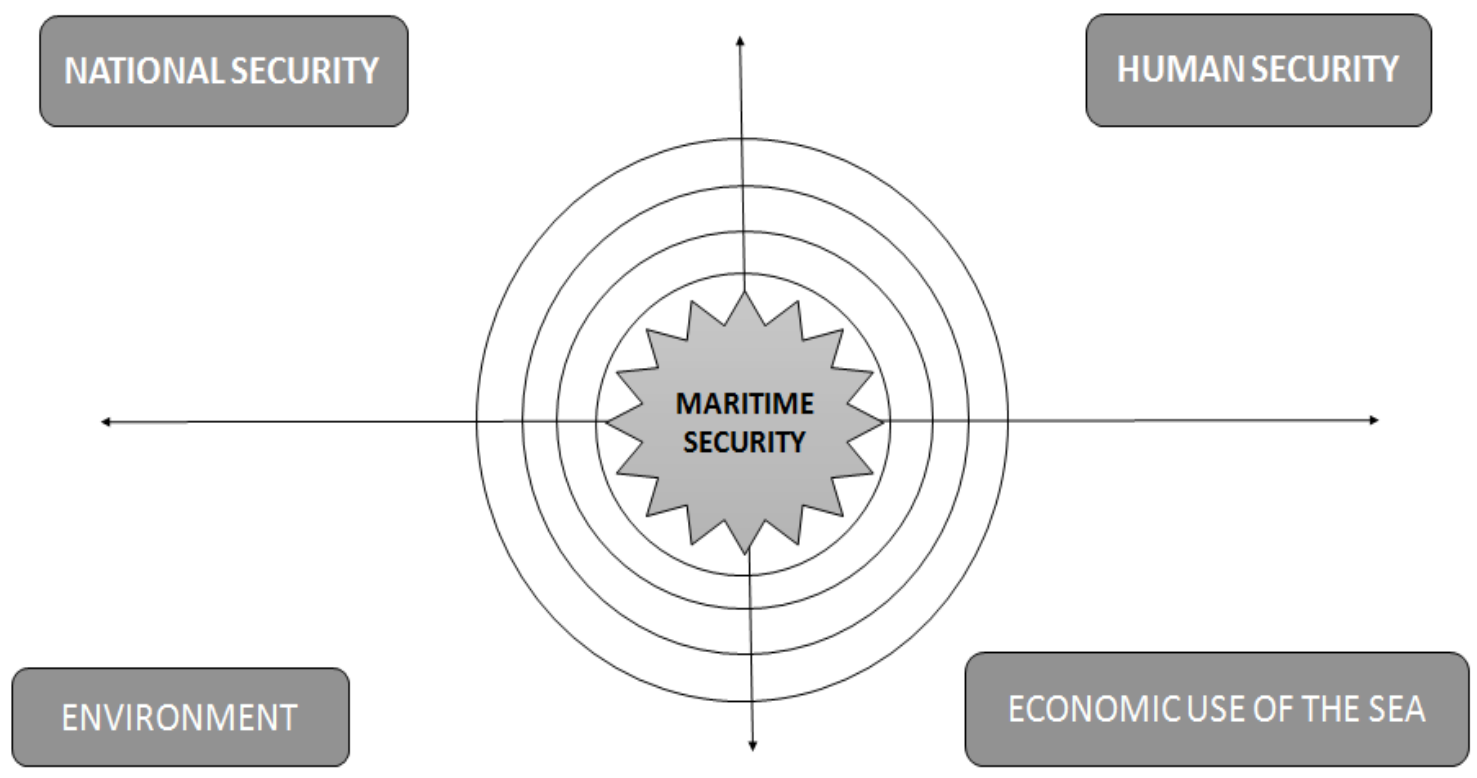

Figure 3. Divergent approach for maritime security.

In these four quadrants, there are sub-thematic ones, some of them are closer to the center, others more peripheral, and it denotes how effectively they are typical issues of maritime security, that is, they would be in the hardcore and that can undergo changes due to national, international interests, dated or timeless. Some themes are almost consensual as belonging to the concept of maritime security, such as inter-state conflicts, piracy (or even armed robbery, when in the territorial sea of states, but this geographical limitation is controversial and deserves a different approach), Corso War (formally considered as a past problem), the typical slave trade (dated and finally abolished), and terrorist acts. To these, new threats have been added and seem to really belong to the concept, such as weapons of mass destruction trafficking, drugs, smuggling, and human trafficking.

However, at present, it is not possible to discuss maritime security by abandoning new themes that are increasingly inserted in this debate, such as the exploitation of living resources (fishing and bioprospecting), exploitation of the seabed, pollution at seas, natural and man-made accidents with serious consequences and even climate change. These themes, although further away from the center, certainly must also be considered. 


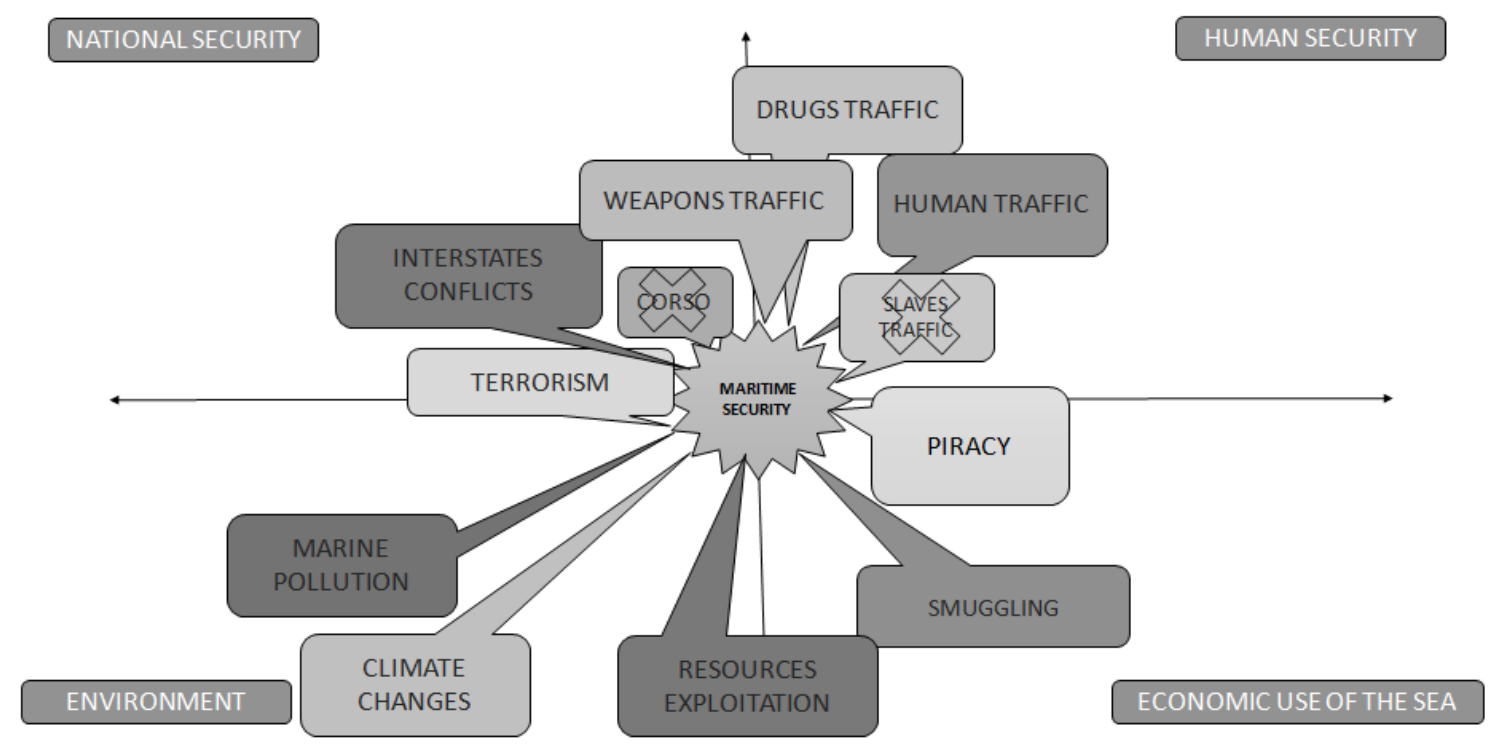

Figure 4. Maritime security threats embedded in the divergent approach.

Therefore, the proposed typology was necessary when considering the concept of maritime security as complex, convergent, and divergent.

So, we have to face this approach to the specific scenario of South Atlantic to try to bring to you how the local perspective has to be considered to understand the problem. If the EU wants to face maritime security challenges abroad their region, it has to try to see the problem from an abroad perspective. Why South Atlantic is a different area from the North Atlantic. At first, that is because of its specific geostrategic and social differences.

There is an enormous distance of defense budgets of each region, and mainly, there are differences between the northern maritime traffic and the southern one. While the first one is almost an east-west traffic, the southern one seems like a wind rose. So, the solutions for each context have to be different.

\section{Using the Proposed Typology}

The possibility of multilateral action to guarantee peace and security at sea presupposes some delimitation. Certainly, actions aimed at combating the exploitation of bioprospecting are quite distinct from actions to avoid drug trafficking or smuggling. On the other hand, starting from the complex typology of maritime security, some of the maritime threats are more localized and have repercussions that are often national or even sub-regional. For example, the problem of illegal fishing in a given area generally affects only the closely economies, tending to be a local community problem, or even practically affecting the coastal State, which sees its right vilified. Other threats have a wider influence, but still have limited repercussions. For example, weapons trafficking, in the Lebanese coast region, is an important geopolitical question to Middle East conflicts, but it cannot be said to have global influence. However, under the possible consequences to the peace and security at sea, the UN urged an answer implementing the Marine Task Force (MTF) to the UN Peacekeeping Mission at Lebanon (UNIFIL) (UN, 2006).

However, some threats are growing to the point of being considered global threats. Some maritime areas have been seen as particularly worrying in terms of maritime security. The East African coast, initially closest 
to the Somali territorial sea, with the increasing pirate attacks, demanded a relevant international response. More recently, the west coast of Africa, the Gulf of Guinea, has also attracted more attention, mostly due to armed robbery, but also piracy. Another problem stemming from maritime insecurity, but of a different cause, has also drawn the attention of international public opinion, which is the question of the flow of migrants and human trafficking in the waters of the Mediterranean Sea.

It is possible to use the proposed typology for the concept of maritime security to the above examples to demonstrate multiple points of view to the threats can and are different. This typology shows itself, particularly when adopted to particularize the understanding of the perceptions and threats of a certain scenario, time, or region. Some of them, internationally engaged, others with more national responses.

Thus, faced with the original questioning of the present work: What does the South Atlantic see as challenges to its maritime security? - we can try to delimit the approach from the proposed typology. The first delimitation is temporal. The first international demonstrations of concern for South Atlantic maritime security have taken on greater form since 2010 when the situation on the East African coast seemed to respond well to the multilateral actions undertaken there. Therefore, the time cut is from 2010. The second clipping is the delimitation of the geographic space that intends to obtain the analysis. For this, it was not based on restricted geographical delimitation: The South Atlantic would be formed only by coastal countries below the Equator. It is considered that such a cut would not be acceptable since the very central area that led to the research (the Gulf of Guinea region) is cut by Parallel Zero and would exclude some relevant actors. How to delimit the South Atlantic then? One could choose different criteria. For example, by the definition of the International Maritime Organization (IMO, 1988), the parallel $160 \mathrm{~N}$ is the delimitation of areas of responsibility of Search and Rescue (Safety) of countries of the South, and then it could be considered only the states below this parallel. Another delimitation could be more geopolitical, for example, since 1996 the treaty establishing the South Atlantic Peace and Cooperation Zone (ZOPACAS) was established by the Brazilian initiative and backed by the UN. Twenty-four African and American coastal states identify themselves as belonging to the South Atlantic and at this treaty. Therefore, we have decided to adopt this methodological cut off the regional variable. It was considered that the Member States of ZOPACAS are identified as South Atlantic ones.

After the preliminary delimitations, we can proceed to analyze the results from the proposed typology. From the complex approach, we would have to analyze the perceptions of four distinct spheres: universal, regional, national, and intra-state. As the answer is directed to the elected regional question (South Atlantic), it would, therefore, be necessary to verify how the other approaches stand concerning the problem. For the sake of simplification of approaches, it was considered that internal (intra-state) issues could be verified at a later and individualized time. Therefore, there are two remaining levels of analysis: the universal and the national.

To map the complex approach of maritime security concerns and initiatives, undertaken by global initiatives, we have elected two international organizations that represent the universal aspiration and their vocations to maritime issues: the UN and IMO. Considering the UN as the "great guardian of international peace and security" (and why not at sea, as well), formal demonstrations were mapped out by its main structural bodies: United Nations Security Council (UNSC) by means of resolutions; letters and specific thematic meetings; UNSC statements; and the General Assembly of the United Nations (GAUN). To IMO's initiatives in the broad spectrum of maritime security, there have been resolutions and conventions from the General Assembly, as well as documents emanating from the Maritime Safety Committee (MSC) of IMO. From this mapping, Table 1 was observed. 
Table 1

Mapping the Complex Approach, at Global Level

\begin{tabular}{|c|c|c|c|c|c|}
\hline \multirow{3}{*}{ Subject } & \multicolumn{5}{|c|}{ International (global) organism (origin of the document) } \\
\hline & \multicolumn{3}{|c|}{$\mathrm{UN}$} & \multicolumn{2}{|l|}{ IMO } \\
\hline & $\begin{array}{l}\text { SCUN } \\
\text { resolution/letter/meetings }\end{array}$ & $\begin{array}{l}\text { SCUN president } \\
\text { statements }\end{array}$ & GAUN & General Assembly & MSC \\
\hline Piracy & $\begin{array}{l}\text { S/RES/2039 (29/02/2012) } \\
\text { S/2016/321 (06/04/2016) } \\
\text { S/PV.7016 (14/08/2013) } \\
\text { S/PV.6668 (23/11/2011) }\end{array}$ & $\begin{array}{l}\mathrm{S} / \mathrm{PRST} / 2012 / 24 \\
(19 / 11 / 2012) \\
\mathrm{S} / \mathrm{PRST} / 2013 / 13 \\
(14 / 08 / 2013) \\
\mathrm{S} / \mathrm{PRST} / 2016 / 4 \\
(26 / 04 / 2016)\end{array}$ & & A/1069 (28) (2013) & \\
\hline Human security & $\begin{array}{l}\text { S/2015/600 (15/10/2014) } \\
\text { S/PV.6668 (23/11/2011) } \\
\text { S/2010/288 (30/06/2010) } \\
\text { SC/11602 (15/10/2014) }\end{array}$ & $\begin{array}{l}\text { S/PRST/2017/14 } \\
(09 / 08 / 2017) \\
\text { S/PRST/2014/24 } \\
(21 / 11 / 2014)\end{array}$ & & $\begin{array}{l}\text { SOLAS Conv. (1974) } \\
\text { SUA Conv. (1988) }\end{array}$ & \\
\hline Human traffic & $\begin{array}{l}\text { S/2017/198 (07/03/2017) } \\
\text { S/PV.8022 (10/08/2017) } \\
\text { SC/11602 (15/10/2014) }\end{array}$ & & & & \\
\hline $\begin{array}{l}\text { Weapons } \\
\text { traffic }\end{array}$ & $\begin{array}{l}\text { S/RES/1467 (18/03/2003) } \\
\text { S/2010/143 (15/03/2010) }\end{array}$ & $\begin{array}{l}\text { S/PRST/2010/6 } \\
(19 / 03 / 2010)\end{array}$ & & & \\
\hline Terrorism & & & $\begin{array}{l}\mathrm{A} / 2017 / 104 \\
(01 / 02 / 2017)\end{array}$ & $\begin{array}{l}\text {-ISPS CODE Conv. } 2002 \\
\text {-Additional Protocol SUA } \\
\text { Conv. (2005) } \\
\text {-Amendment Art. } 2^{\circ} \text { SUA } \\
\text { Conv. (2005) }\end{array}$ & \\
\hline Armed robbery & S/2013/359 (18/06/2013) & & & A/1069 (28) (2013) & $\begin{array}{l}\text { Assisting } \\
\text { Member States } \\
\text { (2014) }\end{array}$ \\
\hline Drugs traffic & $\begin{array}{l}\text { S/2013/728 (5/12/2013) } \\
\text { S/PV.7090 (18/12/2013) }\end{array}$ & $\begin{array}{l}\text { S/PRST/2013/22 } \\
(18 / 12 / 2013)\end{array}$ & & $\begin{array}{l}\text { A.872(20) (27/11/1997) } \\
\text { A/1069 (28) (2013) }\end{array}$ & $\begin{array}{l}\text { Assisting } \\
\text { Member States } \\
(2014) \\
\text { MSC.228(82) } \\
(7 / 12 / 2006)\end{array}$ \\
\hline $\begin{array}{l}\text { Climate } \\
\text { changes }\end{array}$ & S/RES/1625 (14/09/2015) & & $\begin{array}{l}\text { A/63/PV.85 } \\
(03 / 06 / 2009) \\
\text { A/64/350 } \\
(11 / 09 / 2009)\end{array}$ & & \\
\hline $\begin{array}{l}\text { Resources } \\
\text { exploitation }\end{array}$ & & & $\begin{array}{l}\text { A/63/PV.85 } \\
(03 / 06 / 2009) \\
\text { A/64/350 } \\
(11 / 09 / 2009)\end{array}$ & $\begin{array}{l}\text { MARPOL (1973) } \\
\text { Amendment Art. } 2^{\circ} \text { SUA } \\
\text { Conv. (2005) } \\
\text { A/1069 (28) (2013) }\end{array}$ & \\
\hline $\begin{array}{l}\text { Marine } \\
\text { pollution }\end{array}$ & & & & MARPOL (1973) & \\
\hline
\end{tabular}

From the previous Table 1, it is possible to highlight the most incidental global concerns by the complex typology of the concept of maritime security.

Transporting the previous mapping to the proposed quadrants and weighting them according to the scope of the documents emanated, we can build Figure 5 in which subjects are positioned according to the main approaches of the raised documents, being able to be more permeable in more of one of the quadrants and the proximity to the center of the quadrants is due to the most recent concerns (temporal approach) and the size of the tables corresponds to the highest thematic incidence of concerns in relation to international maritime security, reaching Figure 5. 


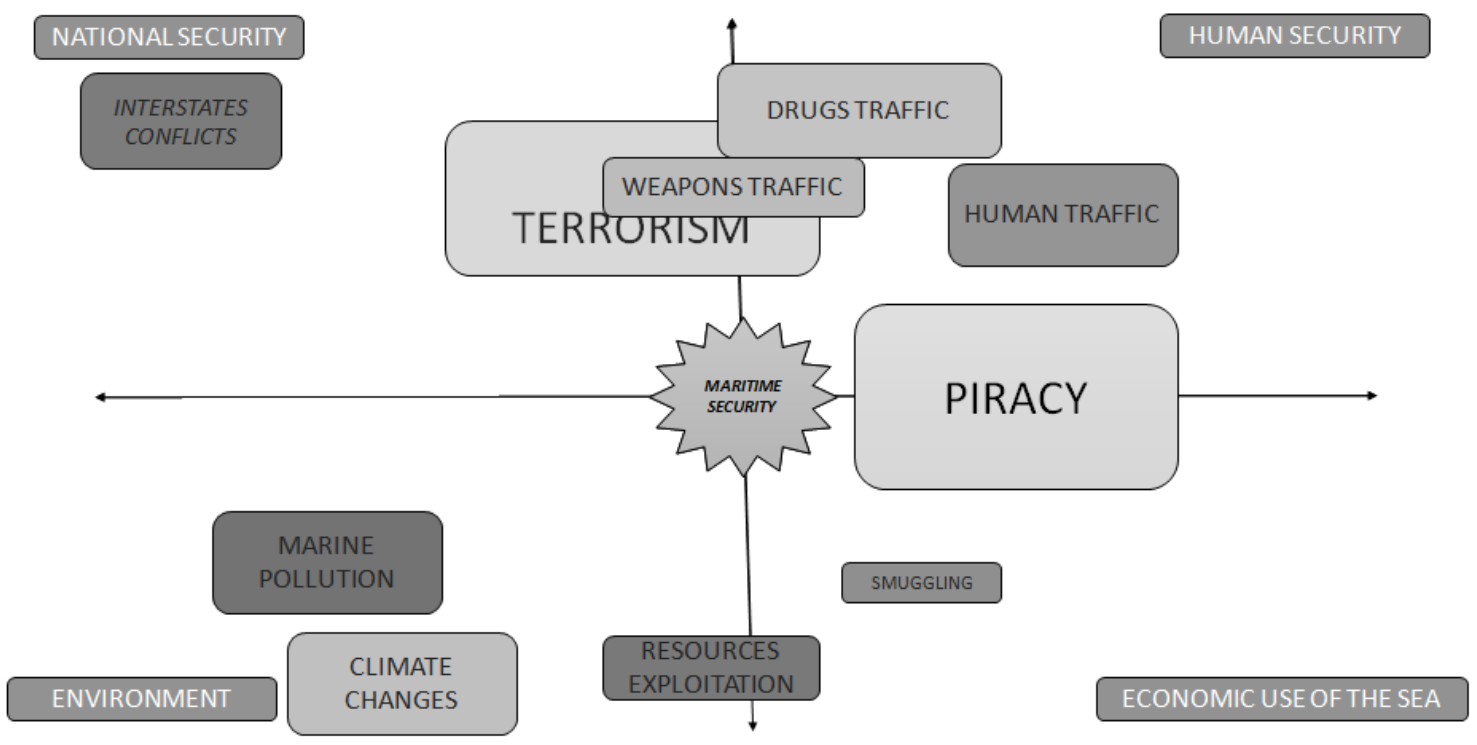

Figure 5. Scheme resulting from the complex global approach in the quadrants.

The next step would be to carry out the same mapping of the neighboring countries to the South Atlantic. To do so, considering the chosen delimitation from the countries of ZOPACAS, we would have to choose the sources of this nationalized perception of each of the 24 countries of ZOPACAS. This could be done by following the same proposal of global sampling, that is, by mapping the main national documents dealing with the subjects (which would imply a very extensive survey and trigger among States, since not all of them live the same institutional and normative maturity).

In July 2016, under the encouragement and support of the IMO in favor of initiatives of regional collaborative arrangements around maritime security, an academic event titled "Experts Panel Meeting-Maritime Security in South Atlantic" was done in Brazil. The purpose of the event was to identify common interests and opportunities for the increase of maritime security in the South Atlantic, as well as to present proposals for the expansion and modernization of the operational capabilities of maritime traffic (MT) monitoring by the countries of the South Atlantic strategic environment. At the occasion, lectures and a seminar game were held, using models of decision-making process simulation (Marinha do Brasil, 2016). The event was attended by significant international representation, with the presence of delegations from 17 South Atlantic States, as well as observers from invited countries (United States of America, France, Portugal, and United Kingdom), from several International Organizations and (IMO), the European Union, the Inter-regional Coordination Center (ICC), based in Cameroon, the South Atlantic Maritime Area Coordinator (CAMAS), and representations of national institutions: the National Control Agency, the Federal Police, National Union of Maritime Shipping Companies (SYNDARMA), and the National Petroleum Agency, among others.

Thus, given the presence of prominent stakeholders from the present states, in spite of it was not the complete ZOPACAS members (17 of 24 States), a part of the chosen methodological method, a controlled interview was conducted to gauge the nationalized perceptions regarding maritime security of each of the present States.

In summary, each stakeholder from each State answered the following questions:

- Which of the following topics are most worrying in terms of maritime security in your area? (Sort from the 
most relevant to the least relevant).

- Observing the chosen themes, assign the percentage of financial commitment and personnel primarily allocated (but not exclusively) to the combat of the threat.

- Observing the chosen themes, assign what should be (IDEALLY) the percentage of financial commitment and personnel primarily allocated (but not exclusively) to the threat.

Based on the answers of the interviewees and not allowing the identification of each State (since there was a commitment of secrecy in the collection of sample data), Table 2 could be constructed:

Table 2

Mapping the Regional Complex Approach (at the National Level) of the South Atlantic Coastal States

\begin{tabular}{|c|c|c|c|c|c|c|c|c|c|c|c|c|}
\hline \multicolumn{2}{|c|}{ State } & \multirow{2}{*}{$\begin{array}{l}\begin{array}{l}\text { Inter-states } \\
\text { conflicts }\end{array} \\
2\end{array}$} & \multirow{2}{*}{$\begin{array}{l}\begin{array}{l}\text { Resources } \\
\text { exploitation }\end{array} \\
1\end{array}$} & \multirow{2}{*}{$\begin{array}{l}\begin{array}{l}\text { Smuggli } \\
\text { ng }\end{array} \\
7\end{array}$} & \multirow{2}{*}{$\begin{array}{l}\begin{array}{l}\text { Climate } \\
\text { changes }\end{array} \\
3\end{array}$} & \multirow{2}{*}{$\frac{\text { Piracy }}{8}$} & \multirow{2}{*}{$\begin{array}{l}\text { Marine } \\
\text { pollution }\end{array}$} & \multirow{2}{*}{$\begin{array}{l}\text { Terroris } \\
\text { m } \\
6\end{array}$} & \multirow{2}{*}{$\begin{array}{l}\text { Weapons } \\
\text { traffic } \\
5\end{array}$} & \multirow{2}{*}{$\begin{array}{l}\begin{array}{l}\text { Drugs } \\
\text { traffic }\end{array} \\
9\end{array}$} & \multirow{2}{*}{$\begin{array}{l}\begin{array}{l}\text { Human } \\
\text { traffic }\end{array} \\
10\end{array}$} & \multirow[t]{2}{*}{ Others } \\
\hline & Priority & & & & & & & & & & & \\
\hline \multirow[t]{3}{*}{ A } & $\%$ at now & 35 & 15 & 5 & 5 & 5 & 10 & 5 & 5 & 10 & 5 & \\
\hline & $\%$ ideal & 40 & 25 & 0 & 0 & 15 & 10 & 10 & 0 & 0 & 0 & \\
\hline & Priority & 2 & 1 & 7 & 8 & 9 & 4 & 3 & 6 & 5 & 10 & \\
\hline \multirow[t]{3}{*}{ B } & $\%$ at now & 30 & 20 & 5 & 0 & 5 & 10 & 10 & 10 & 10 & 0 & \\
\hline & $\%$ ideal & 30 & 30 & 0 & 0 & 0 & 10 & 10 & 10 & 10 & 0 & \\
\hline & Priority & 7 & 5 & 4 & 10 & 1 & 2 & 8 & 6 & 3 & 9 & \\
\hline \multirow[t]{3}{*}{$\mathrm{C}$} & $\%$ at now & 15 & 10 & 15 & 0 & 15 & 15 & 10 & 10 & 10 & 0 & \\
\hline & $\%$ ideal & 15 & 15 & 15 & 5 & 10 & 10 & 15 & 5 & 5 & 5 & \\
\hline & Priority & 7 & 1 & 2 & 10 & 3 & 6 & 4 & 5 & 9 & 8 & \\
\hline \multirow[t]{3}{*}{ D } & $\%$ at now & 10 & 40 & 10 & 0 & 15 & 0 & 10 & 10 & 10 & 5 & \\
\hline & $\%$ ideal & 20 & 40 & 10 & 5 & 10 & 5 & 10 & 0 & 0 & 0 & \\
\hline & Priority & 3 & 4 & 2 & 10 & 1 & 9 & 5 & 6 & 7 & 8 & Control \\
\hline \multirow[t]{3}{*}{ E } & $\%$ at now & 10 & 5 & 5 & 0 & 30 & 0 & 15 & 10 & 5 & 5 & 15 \\
\hline & $\%$ ideal & 10 & 5 & 5 & 0 & 30 & 0 & 15 & 10 & 5 & 5 & 15 \\
\hline & Priority & 10 & 2 & 7 & 9 & 3 & 8 & 1 & 4 & 5 & 6 & \\
\hline \multirow[t]{3}{*}{$\mathrm{F}$} & $\%$ at now & 10 & 10 & 10 & 0 & 10 & 5 & 15 & 15 & 15 & 10 & \\
\hline & $\%$ ideal & 10 & 10 & 10 & 0 & 10 & 5 & 15 & 15 & 15 & 10 & \\
\hline & Priority & 6 & 8 & 1 & 9 & 7 & 10 & 2 & 3 & 4 & 5 & \\
\hline \multirow[t]{3}{*}{ G } & $\%$ at now & 10 & 0 & 35 & 0 & 10 & 10 & 10 & 10 & 10 & 5 & \\
\hline & $\%$ ideal & 10 & 0 & 35 & 0 & 10 & 10 & 10 & 10 & 10 & 5 & \\
\hline & Priority & 9 & 5 & 8 & 10 & 4 & 7 & 6 & 1 & 2 & 3 & Control \\
\hline \multirow[t]{3}{*}{$\mathrm{H}$} & $\%$ at now & 5 & 10 & 5 & 0 & 10 & 0 & 10 & 20 & 10 & 10 & 20 \\
\hline & $\%$ ideal & 10 & 10 & 10 & 0 & 20 & 0 & 10 & 10 & 10 & 10 & 10 \\
\hline & Priority & 8 & 6 & 3 & 9 & 1 & 10 & 2 & 5 & 4 & 7 & \\
\hline \multirow[t]{3}{*}{ I } & $\%$ at now & 10 & 10 & 5 & 10 & 20 & 10 & 20 & 5 & 5 & 5 & \\
\hline & $\%$ ideal & 10 & 10 & 5 & 10 & 20 & 10 & 20 & 5 & 5 & 5 & \\
\hline & Priority & 3 & 4 & 2 & 10 & 1 & 9 & 5 & 6 & 7 & 8 & \\
\hline \multirow[t]{3}{*}{$\mathrm{J}$} & $\%$ at now & 20 & 10 & 5 & 0 & 30 & 0 & 15 & 10 & 5 & 5 & \\
\hline & $\%$ ideal & 20 & 10 & 5 & 0 & 30 & 0 & 15 & 10 & 5 & 5 & \\
\hline & Priority & 8 & 1 & 2 & 10 & 4 & 9 & 3 & 5 & 6 & 7 & \\
\hline \multirow[t]{3}{*}{ K } & $\%$ at now & 10 & 20 & 20 & 0 & 10 & 0 & 10 & 10 & 10 & 10 & \\
\hline & $\%$ ideal & 10 & 20 & 15 & 0 & 10 & 5 & 10 & 10 & 10 & 10 & \\
\hline & Priority & 3 & 4 & 2 & 10 & 1 & 9 & 5 & 6 & 7 & 8 & \\
\hline \multirow[t]{2}{*}{$\mathrm{L}$} & $\%$ at now & 20 & 10 & 5 & 0 & 30 & 0 & 15 & 10 & 5 & 5 & \\
\hline & $\%$ ideal & 20 & 10 & 5 & 0 & 30 & 0 & 15 & 10 & 5 & 5 & \\
\hline
\end{tabular}


(table 2 continued)

\begin{tabular}{|c|c|c|c|c|c|c|c|c|c|c|c|c|}
\hline \multicolumn{2}{|c|}{ State } & \multirow{2}{*}{$\begin{array}{l}\begin{array}{l}\text { Inter-states } \\
\text { conflicts }\end{array} \\
9\end{array}$} & \multirow{2}{*}{$\begin{array}{l}\text { Resources } \\
\text { exploitation } \\
8\end{array}$} & \multirow{2}{*}{$\begin{array}{l}\text { Smuggli } \\
\text { ng } \\
1\end{array}$} & \multirow{2}{*}{$\begin{array}{l}\text { Climate } \\
\text { changes }\end{array}$} & \multirow{2}{*}{$\begin{array}{l}\text { Piracy } \\
3\end{array}$} & \multirow{2}{*}{$\begin{array}{l}\text { Marine } \\
\text { pollution }\end{array}$} & \multirow{2}{*}{$\begin{array}{l}\text { Terroris } \\
\mathrm{m} \\
2\end{array}$} & \multirow{2}{*}{$\begin{array}{l}\text { Weapons } \\
\text { traffic } \\
4\end{array}$} & \multirow{2}{*}{$\begin{array}{l}\begin{array}{l}\text { Drugs } \\
\text { traffic }\end{array} \\
5\end{array}$} & \multirow{2}{*}{$\begin{array}{l}\text { Human } \\
\text { traffic } \\
6\end{array}$} & \multirow{2}{*}{ Others } \\
\hline & Priority & & & & & & & & & & & \\
\hline \multirow[t]{3}{*}{ M } & $\%$ at now & 0 & 0 & 25 & 0 & 25 & 5 & 25 & 5 & 5 & 5 & \\
\hline & $\%$ ideal & 0 & 0 & 25 & 0 & 25 & 5 & 25 & 5 & 5 & 5 & \\
\hline & Priority & 7 & 1 & 2 & 10 & 3 & 6 & 4 & 5 & 9 & 8 & \\
\hline \multirow[t]{3}{*}{$\mathrm{N}$} & $\%$ at now & 10 & 40 & 10 & 0 & 15 & 0 & 10 & 10 & 10 & 5 & \\
\hline & $\%$ ideal & 20 & 40 & 10 & 5 & 10 & 5 & 10 & 0 & 0 & 0 & \\
\hline & Priority & 7 & 1 & 2 & 10 & 4 & 9 & 3 & 5 & 6 & 8 & \\
\hline \multirow[t]{3}{*}{$\mathrm{O}$} & $\%$ at now & 5 & 25 & 20 & 0 & 20 & 0 & 20 & 5 & 5 & 0 & \\
\hline & $\%$ ideal & 15 & 20 & 15 & 0 & 15 & 5 & 15 & 10 & 5 & 5 & \\
\hline & Priority & 8 & 6 & 3 & 9 & 1 & 10 & 2 & 5 & 4 & 7 & \\
\hline \multirow[t]{3}{*}{$\mathrm{P}$} & $\%$ at now & 10 & 10 & 5 & 10 & 20 & 10 & 20 & 5 & 5 & 5 & \\
\hline & $\%$ ideal & 10 & 10 & 5 & 10 & 20 & 10 & 20 & 5 & 5 & 5 & \\
\hline & Priority & 9 & 8 & 1 & 10 & 3 & 7 & 2 & 4 & 5 & 6 & \\
\hline \multirow[t]{2}{*}{ Q } & $\%$ at now & 10 & 0 & 25 & 0 & 25 & 5 & 15 & 5 & 5 & 5 & \\
\hline & $\%$ ideal & 10 & 0 & 25 & 0 & 25 & 5 & 15 & 5 & 5 & 5 & \\
\hline
\end{tabular}

The previous Table 2 allows some analysis. The first refers to whether or not we can consider the representative sample of the whole. It would be necessary to ensure that the most disparate shades among states, whether by size, economic power, location (South American or African), and cultural identities were represented. These aspects were fully met. Other analyses call for attention, for example, the fact that the vast majority of states said the low possibility of inter-state conflicts, and therefore, with a lower (current and ideal) allocation of resources to classic weapons of naval warfare, they highlighted a low priority to this threat.

However, in order to extract the mapping to be used in the divergent typology of insertion in the four quadrants with the appropriate correspondence of proximity and size, the average priorities for approaching (or withdrawing from the center) and size of the threat perception frame of a given subject, the average current percentage of resources allocated in that prevention. From this relation, Table 3 was built.

Table 3

Mapping the Complex, Consolidated Approach at Regional Level

\begin{tabular}{|c|c|c|c|c|c|c|c|c|c|c|c|}
\hline Average & $\begin{array}{l}\text { Inter-states } \\
\text { conflicts }\end{array}$ & $\begin{array}{l}\text { Resources } \\
\text { exploitation }\end{array}$ & Smuggling & $\begin{array}{l}\text { Climate } \\
\text { changes }\end{array}$ & Piracy & $\begin{array}{l}\text { Marine } \\
\text { pollution }\end{array}$ & Terrorism & $\begin{array}{l}\text { Weapons } \\
\text { traffic }\end{array}$ & $\begin{array}{l}\text { Drugs } \\
\text { traffic }\end{array}$ & $\begin{array}{l}\text { Human } \\
\text { traffics }\end{array}$ & Others \\
\hline & 6.35 & 3.76 & 3.29 & 9.23 & 3.35 & 7.41 & 3.7 & 4.76 & 5.7 & 7.17 & \\
\hline$\%$ at now & 12.74 & 13.82 & 12.35 & 1.4 & 17.35 & 4.7 & 13.52 & 9.11 & 9.01 & 5 & $(1.75)$ \\
\hline
\end{tabular}

Table 3, taken as summing up of national interests of the region, which in itself may already mean simplification and generalization that does not accurately reflect regional longings, when understood as an indivisible whole, already allows for some secondary analysis. The smaller the (relative) number of priorities is, the greater the priority of the South Atlantic States is. Thus, it is perceived that the highest priority of the States in terms of maritime security is smuggling, showing the importance given to the economic aspect of the national relationship with the sea. Soon closer, it comes the concern with piracy, which, in a way, would converge with the global perception. However, unlike the global perspective, the third major concern is maritime terrorism (3.7) (due to the inherent risk of exploitation of marine resources, especially hydrocarbons), which almost coincides with the fourth-highest priority, the sustainable exploitation of ocean resources (3.76). 
That is, the character of economic use of the seas is central to the South Atlantic countries and does not correspond to the second-highest global priority, which would be human trafficking (adding human security to the effective trafficking of migrants and refugees) and not even trafficking drugs or weapons. These threats would be even less relevant than interstate conflicts.

Therefore, as it was done to global interests, it is possible to construct the graphic illustration of the resulting average of national interests in the region, as follows:

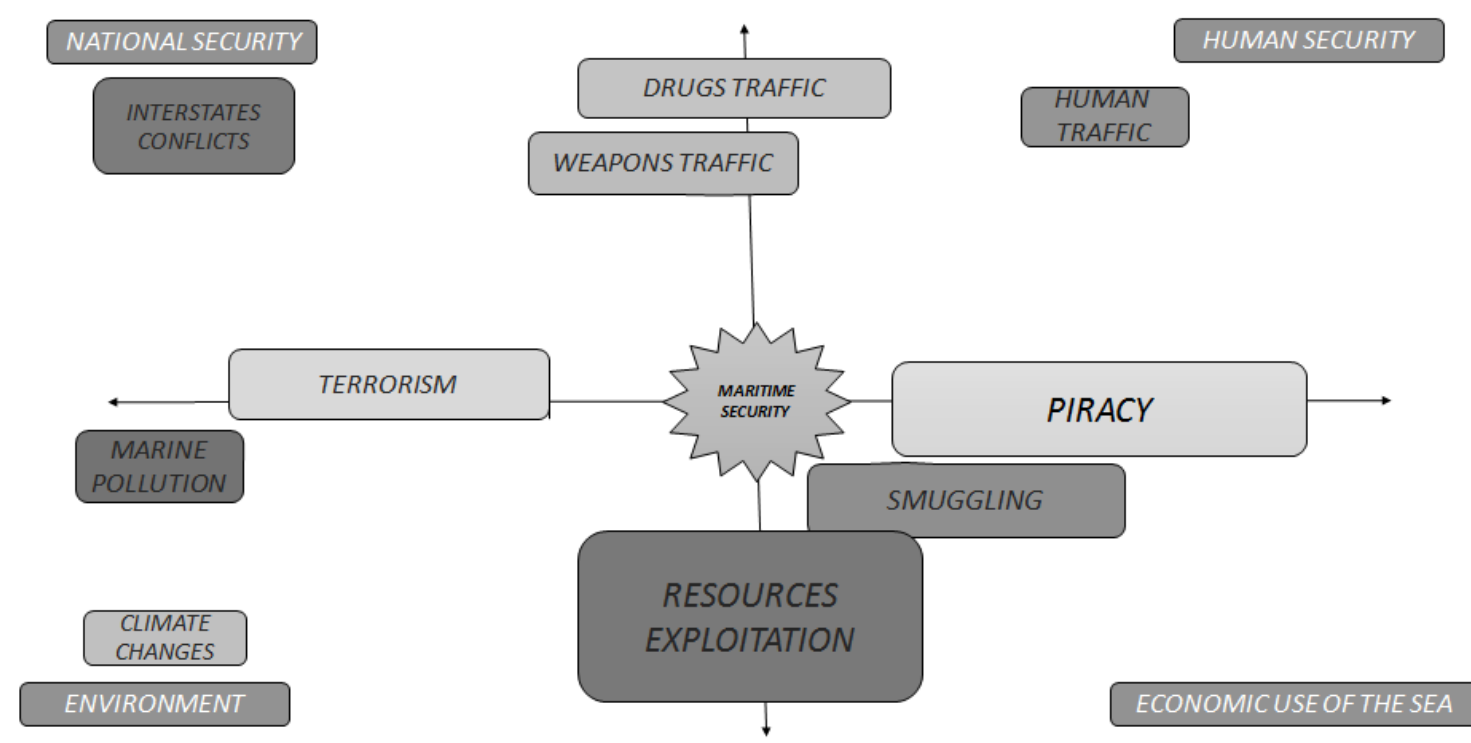

Figure 6. Divergent approach: scheme resulting from the complex approach of the sum of national interests (regional) in the quadrants.

Thus, to achieve the purpose of ensemble analyses from the convergent and complex aspirations of the maritime security having in mind the regionalized understanding of the South Atlantic, it is possible to overlap the divergent global perspective at the average of the national approaches, in a single graphic, as follows:

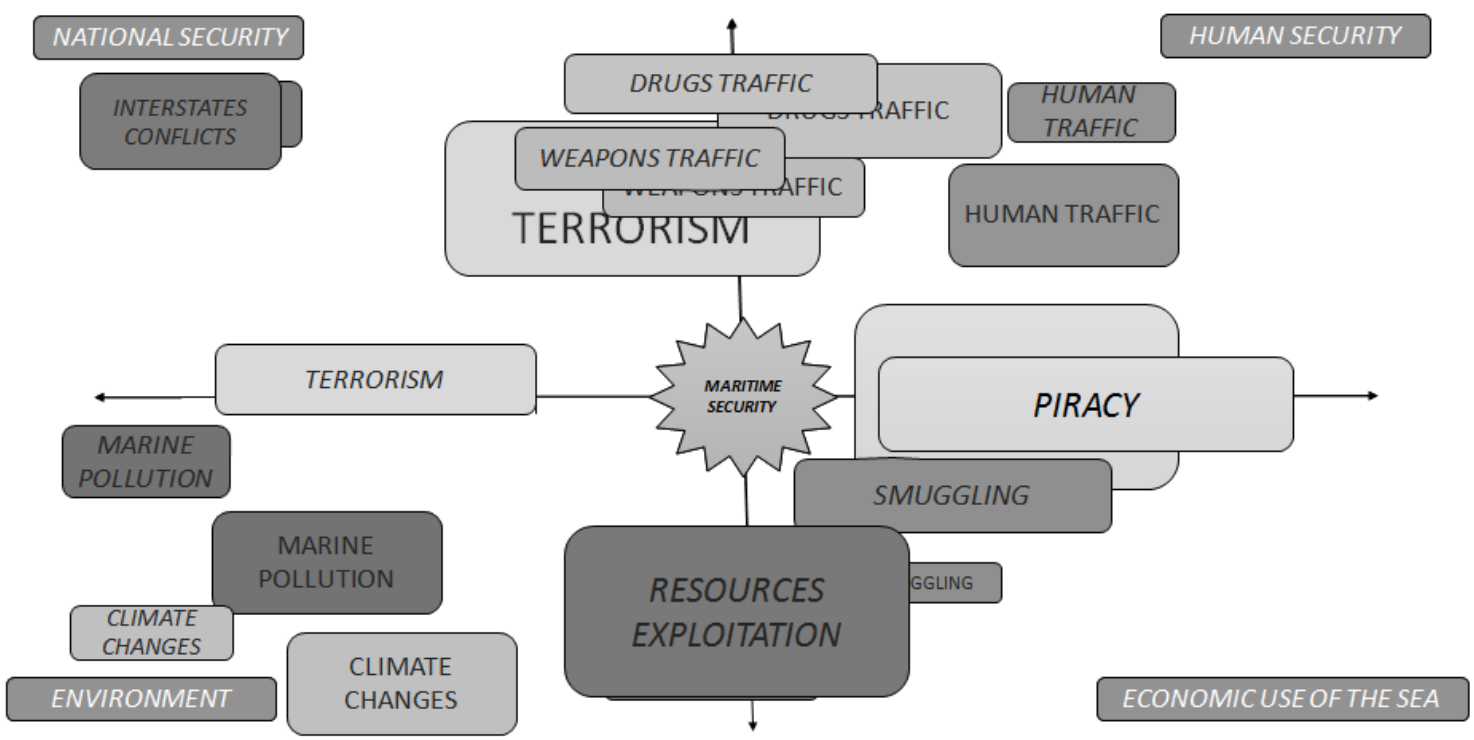

Figure 7. Scheme of coincidence of "global" and "regional" divergent approaches. 
From Figure 7, we can deduce a reasonable different point of view between the approaches (global and regional) and it deserves special analysis to the purpose of the present work. It should be noted that the regional interests' framework was represented in italics letters.

It can be deduced from it that the major international concerns with maritime security are not linearly reflected in the reading of the South Atlantic countries that have a concern related to their realities and local and regional demands.

What would be the relevance of the proposed typology?

The greatest commitment to co-operating and co-operative assistance from states is certainly greater when one fills it's aware of the problem. So, that is the relevance of observing the problem under the point of view of who lives it. Thus, we can achieve greater engagement in the points of convergence of perceptions, as can be seen from the intersection scheme of South Atlantic interests.

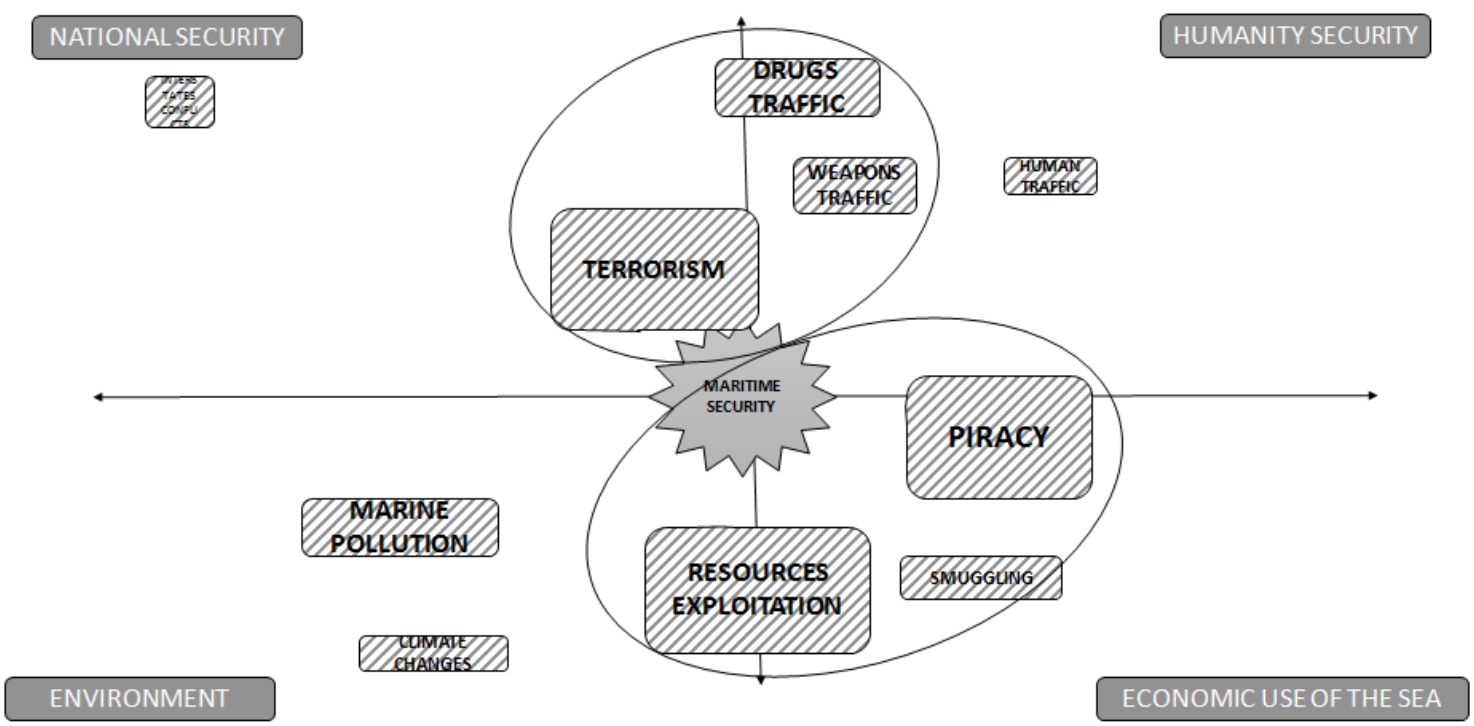

Figure 8. Intersections of major South Atlantic concerns in terms of maritime security.

In other words, demanding aid and cooperation from the South Atlantic States to climate changes, resulting from maritime actions, may not lead to a great deal of engagement from them. But, not everything is dissonant; the issue of concern about piracy is certainly a coincident point, but it is not the only one or the greater, South Atlantic countries demands are more related to the risks inherent to ocean resources (fishing and, especially, exploitation of hydrocarbons) and well reflected with fears of attacks on its sustainable exploitation of resources and possible terrorist action on these offshore platforms.

What would be the validity of this work? It is addressed to Identify convergent points of interest that allow closer actions and political will to engage in collaborative and joint actions that, in the end, would also converge to the demands for greater maritime security in the South Atlantic-a regional maritime security policy.

\section{South Atlantic Maritime Security Cooperation Initiatives}

To see if the proposed typology is adequate, it would be necessary to verify whether if there are initiatives (in all shades) to increase South Atlantic maritime security. Two evaluations are possible: The first one, to 
verify whether or not initiatives have already been adopted and implemented, and the second one, the possibility of new initiatives resulting from the regional identity evaluation of their problems.

From the "complex approach", we can see both initiatives: top-down and bottom-up. There are identifiable global cooperation initiatives, for example, by the mobilization of the UN at its highest level in terms of ensuring international peace and security, namely its UN Security Council, which has repeatedly called on States to cooperate in combating maritime threats in the so-called region of the Gulf of Guinea. Another example of a global initiative is the engagement of the International Maritime Organization's (IMO) Safety Committee to stimulate private and state actions to increase maritime security control methods to the maritime traffic in the region.

From the regional point of view, initiatives can also be checked by grouping interests. However, perhaps, this is the biggest challenge to be faced. The two Atlantic shores, in terms of regional arrangements, have not had effective interlocking and cooperative actions. On the African side of the South Atlantic, there are initiatives, such as the formation of the "Yaoundé Forum" created by the Gulf of Guinea Commission (August 10, 2013); or by the African Union in developing the "2050 Africa's Integrated Maritime Strategy", which has been in action since January 2014 and has already led to effective actions such as the signing of the "Lomé Charter" (October 15, 2016) with indicators and specific actions to the Gulf of Guinea. It put together 32 African Member States. On the other side of the Atlantic, the major concerns do not arise from the perspective of piracy, since the South American Coast can be considered almost unaffected by this maritime threat. Thus, most of the South American regional initiatives in terms of maritime security have been constituted to "control and monitoring of maritime traffic" and in the sharing of information that increases maritime situational awareness.

From national initiatives, the mapping of bilateral or plurilateral agreements (which differs from multilateral ones because they do not have the open bias of the latter, with the possibility of increasing participation by interested parties) allows seeing existing partnerships and mutual trust measures. There is clear identification of the African States that are constantly together, as well as the reverse. From the South American point of view also, most of the initiatives are plurilateral (Brazil, Argentina, Uruguay, and Paraguay), but there are also cross-initiatives, such as the South African partnerships with Argentina and Uruguay. It is also possible to mention several bilateral Brazilian actions, such as Namibia—by assisting the institutional construction of its Navy-or Angola-in terms of interests related to oil exploitation, or even, to São Tomé and Príncipe (resulting from Portuguese Speaking Countries Community—known as CPLP).

However, none of these actions were of great effectiveness to the strict object of the present study, that is, the increase of maritime security in the South Atlantic. In this sense, the most effective actions have been adopted by the lowest level of the complex approach, which is the interstate or institutional initiative. It is possible to see some examples of partnerships that have been consolidating in Africa since the Maritime Exercise Operation of Control of Restricted Maritime Area, called OBANGAME, or even of initiatives of technology exchange and Brazilian Navy training operations in some African Navies ${ }^{1}$.

However, it is not possible to identify bigger initiatives, by the complex approach, to face their main concerns of maritime security. There is not a strong link between the actions and the higher expectations in

\footnotetext{
${ }^{1}$ As examples of these partnerships between Brazilian Navy and African Navies, it is possible to point the information sharing from SIMMAP-System for Tracking Oil Activity, PRENAV—System for Tracking Inland Water Boats, or the PREPS-System for Tracking Fishing Boats.
} 
terms of threats considered as priorities. There is, therefore, a relative distance from the initiatives carried out and the actual local and regional demands.

\section{Final Remarks}

Guided by the initial purpose of the present work in seeking to address the issue of delimitation of maritime security in the South Atlantic region, an attempt has been made to demonstrate how difficult this delimitation can be. The presented proposal was the use of a specific typology to aid the identification of the regional perceptions, derived from the national perceptions, focused on the main factors that are considered as an increase of the insecurity sensation at South Atlantic Ocean.

It was tried to demonstrate that there is a significant extra-regional worldwide effort in encouraging actions to increase maritime security, often this effort starts from premises of exogenous observations with insipient dialogue with the relevant factors involved in the process. Thus, in spite of various cooperation initiatives at a global, extra-regional and regional level (both from regional and international organizations, such as ZOPACAS and CPLP), national and even intra-national (by institutions and even non-governmental), it cannot be said that the South Atlantic has been perceived as safer post-initiatives. So, what would be the motive? Actions poorly planned or poorly executed? Certainly, such findings can be evidenced in another research, however, what has been tried to demonstrate from the national to the regional identification, is that the main factors of destabilization of the feeling of security at sea have not been the most affected by the actions implemented under development extra-regional.

Thus, rather than presenting conclusive solutions, the present research raises the reflection of the continuous need (institutional and individual) for stripping bias arising from reality other than that of the focus of the problem and that, this exercise, in addition to the actions, carried out always reinforce identities and reputations.

\section{References}

2050 Africa's Integrated Maritime Strategy (2050 AIM STRATEGY). (2012). Retrieved 13th July, 2017, from http://cggrps.org/wp-content/uploads/2050-AIM-Strategy_EN.pdf

African Union. (2016). Lomé charter. Retrieved 15th July, 2017, from https://issafrica.org/iss-today/fulfilling-the-promise-of-the-lome-maritime-summit

Alliance Maritime Strategy. (2011). North Atlantic Treaty Organization (NATO). Retrieved from http://www.nato.int/cps/en/natohq/official_texts_75615.htm

Beirão, A. P., \& Pereira, A. C. A. (Org.). (2014). Reflexões sobre a Convenção do Direito do Mar (1st ed.). Brasília: Fundação Alexandre de Gusmão.

Buerger, Christian. (2014). What is maritime security? Retrieved from http://bueger.info/wp-content/uploads/2014/12/Bueger-2014-What-is-Maritime-Security-final.pdf

Ferrajoli, L. (2009). A Soberania no mundo moderno. São Paulo: Martins Fontes.

Grotius, H. (1609). The freedom of the seas, or the right which belongs to the Dutch to take part in the East Indian Trade (Trad. Ralph Van Deman Magoffin). Ver. 1916. New York: Oxford University Press.

International Maritime Organization (IMO). (1988). Convention for the suppression of Unlawful Acts of Violence against the Safety of Maritime Navigation (SUA Convention). Retrieved 20th September, 2017, from http://www.un.org/en/sc/ctc/docs/conventions/Conv8.pdf

Kraska, J., \& Pedrozo, R. (2013). International maritime security law. London: Martinus Nijhoff Publishers.

Marinha do Brasil. (2016). Experts panel meeting-Maritime security in South Atlantic. Retrieved 10th August, 2017, from https://www.marinha.mil.br/comcontram/?q=content/15-17062016-semin\%C3\%A1rio-sobre-seguran\%C3\%A7a-mar\%C3\% ADtima-no-atl\%C3\%A2ntico-sul 
Till, G. (2012). The rise of naval power in Asia-Pacific. London: Routledge.

United Nations. (2006). United Nations security council resolution. S/Res./1701. Retrieved 10th May, 2017, from https://documents-dds-ny.un.org/doc/UNDOC/GEN/N06/465/03/PDF/N0646503.pdf?OpenElement 